\title{
Australian On-Market Buy-backs: An Examination of Valuation Issues
}

\author{
Jason Mitchell \\ University of Michigan Business School, U.S.A. \\ H. Y. Izan \\ University of Western Australia, Australia \\ Roslinda Lim \\ Macquarie University, Australia
}

\begin{abstract}
A compelling reason for engaging in on-market buy-backs is that it provides a signal about the undervaluation of the company. In this paper an alternative, accounting based, method of determining fundamental value and undervaluation is used, namely the Ohlson residual income valuation framework. It is found that prior to the announcement buy-back companies are significantly undervalued relative to comparable non-buy-back companies. This undervaluation is largely but not totally removed in the period immediately following the on-market buy-back implying on-market buy-backs are predominantly an effective signaling mechanism. Where the firm cites undervaluation as a specific motive for the buy-back then, in fact, a higher degree of undervaluation prior to the buy-back is evident. The results provide evidence that management can, and does, identify undervaluation and reduces this through the signaling mechanism of on-market buy-backs (JEL: G34, G35, G38).
\end{abstract}

Keywords: buy-backs, undervaluation, fundamental value.

\footnotetext{
* This paper has benefited from helpful comments from Ben-Hsien Bao, Neal Arthur, Graeme Dean, Tom Nohel, Raymond Da Silva Rosa, Philip Lee, Mark Moore, Vanitha Ragunathan and Terry Walter, participants of workshops at Macquarie University, University of Sydney, the 2002 AAANZ conference as well as two anonymous reviewers. Special thanks are extended to Grace Dharmawan for compiling the buy-back database over the January 1996 to June 1997 period. Jason Mitchell acknowledges financial support from the Hong Kong Polytechnic University RGC grant number G-YC25 for this project. We thank I/B/E/S for the use of analyst forecast data.
}

(Multinational Finance Journal, 2006, vol. 10, no. 1/2, pp. 43-79)

(C) Multinational Finance Society, a nonprofit corporation. All rights reserved. DOI: $10.17578 / 10-1 / 2-2$ 


\section{Introduction}

The U.S. has had a long history with respect to share repurchases. In 1995 alone, the use of share repurchases resulted in a net reduction of U.S. $\$ 2.3$ billion worth of shares with the dollar amount of buy-backs exceeding the amount of new shares issued. Considerable evidence exists that the financial market reacts favorably to the announcement of open-market repurchases or buy-backs. ${ }^{1}$ It is well established the average positive abnormal return from open market repurchase announcements by U.S. companies is significant and on average 2 to 3 percent. ${ }^{2}$ Similarly, for Australian companies conducting on-market buy-backs, the average abnormal return is again a significant 2 to 3 percent. In more recent years, the Australian evidence is that the market reaction is now greater and of the order of 4 to 5 percent. ${ }^{3}$

A number of motivations have been proposed as possible explanations for the overall positive market reaction to buy-backs (see Mitchell and Robinson, [1999]). One that receives constant and wide support in the literature and from management is the "signaling of undervaluation" explanation. Surveys of management for U.S. companies (see Baker, Gallagher and Morgan, [1981]; Wansley, Lane and Sarkar [1989] and Tsetsekos, Kaufman and Gitman, [1991]); and for Australian companies (Mitchell and Robinson, [1999] and Mitchell, Dharmawan and Clarke, [2001]) have all reported signaling of undervaluation is one of the most common cited motives for on-market buy-back activity. The undervaluation motivation has remained prominent over time. A recent survey of U.S. managers of firms engaging in open-market repurchases by Baker, Powell and Veit (2003) found that while the importance that management attaches to some reasons for repurchasing has changed, signaling of undervaluation remains the most prominent.

The Australian market provides a unique environment to test the

1. The terms share buy-backs and share repurchases are used interchangeably in this paper and refer to the situation where a company acquires its own shares or previously issued capital.

2. For instance, U.S. studies such as Dann (1981), Vermaelen (1981), Comment and Jarrell (1991) and Ikenberry, Lakonishok and Vermaelen (1995) to name a few.

3. Harris and Ramsay (1995), Christianto, Clarke and Mitchell (1997), Lamba and Ramsay (2000) and Balachandran and Troiano (2000) all provide evidence for the Australian environment. 
undervaluation theory for a number of reasons. First, the institutional and structural aspects of Australian buy-backs are vastly different from that of U.S. and even other Commonwealth countries such as the U.K. As an obvious illustration of the structural differences, different types of buy-backs are permitted in Australia in contrast with the U.S. ${ }^{4}$ Structural differences are highlighted in the requirement for Australia that a formal announcement of the intention to buy-back must be made together with details regarding the timing, extent of the repurchase and participation of directors. Investors are thus well informed, the buy-back activity is transparent and disclosed from start to finish. Moreover the announcement in Australia is more definite in its statement and is not effectively a general mandate as it is in the U.S. (Stephens and Weisbach, [1998]). Most importantly, Australian companies must disclose the motive of the buy-back in their announcement. This is unique from all other repurchase environments. Finally, there have been two distinct regulatory regimes in Australia. The simplification of the buy-back requirements in December 1995 allows us to logically expect different managerial responses and motivation over the different time periods. The reduction in costs and ease with which buy-backs can be conducted may enable them to be more readily employed as a signaling mechanism following the change.

Combined, the above aspects provide anecdotal evidence that undervaluation is likely to be a stronger driving force for buy-backs in Australia relative to other countries. Moreover, the study contributes to the literature as an accounting based valuation technique is used to identify undervaluation. This is valuable and it is argued that it provides a powerful alternative to studies that simply consider share market response. Accounting based valuation techniques have not been used previously within the buy-backs context so the study explores new ground in this area.

Specifically, this paper examines whether buy-back companies are undervalued relative to non-buy-back companies and whether the undervaluation (if any) is reduced after the buy-back announcement. Another aspect is if the undervaluation manifests itself more (i) for buy-backs post the 1995 legislative change, (ii) by companies that cite a motivation of undervaluation, and/or alternatively (iii) for initial

4. The appropriate requirements in the Corporations Law legislation are currently contained in sections 257A-257J. For a detailed comparison of the differences in the institutional framework of buy-backs in Australia relative to other markets see Dharmawan and Mitchell (2001). 
buy-back activity. Finally, the paper considers whether (any) differences in undervaluation are related to relevant characteristics of firms or the actual buy-back.

As expected, systematic undervaluation is discovered only for on-market buy-backs. Prior to the on-market buy-back announcements companies are significantly undervalued relative to a control sample. In general, on-market buy-backs are a useful and predominantly effective signaling mechanism. Following the introduction of the regulatory change in December 1995, undervaluation prior to the buy-back is more pronounced, consistent with previous studies that document greater share price reaction for this later period (Lamba and Ramsay, [2000]). The most notable result is that a larger degree of prior undervaluation occurs for those buy-back events where undervaluation is explicitly identified as a motive. This confirms management can identify undervaluation and takes steps to address it through on-market buy-backs. Contrary to expectations, initial buy-backs or those conducted for the first time have less undervaluation and signaling in comparison with repeat buy-backs. The lower signaling power of initial buy-backs may be due to repeat buy-backs being more convincing in their motive of signaling undervaluation.

In the next section, a brief discussion on some relevant institutional issues is provided. This is followed by a review of relevant literature on buy-backs and the specific research questions in section III. The data and research method are discussed in section IV. Results are then presented in section $\mathrm{V}$, followed by concluding remarks in section VI.

\section{Institutional Issues}

Prior to 1989 companies in Australia were prohibited from repurchasing their shares and could only reduce capital through a complex and costly capital reduction scheme that required court approval. Finally, after much debate, the legislation removing the prohibition against share repurchases came into effect on 1 November 1989. Hence, for Australia share buy-backs are a relatively new phenomenon. Contrary to expectations though, the initial legislation was not successful. In the first few years following the lifting of the share buy-back prohibition, only a few companies availed themselves of the new capital restructuring technique due to the complex legal requirement and restrictions contained in the original legislation. This made early 
buy-backs a costly and difficult exercise. There was also the initial scepticism of Australian managers unfamiliar with the buy-back mechanism and the lack of major prominent "blue-chip" companies that engaged in this activity.

In order to address the lack of buy-back activity as well as the onerous legislative provisions the First Corporate Law Simplification Bill and subsequent Act (FCLSA) was introduced effective December 1995. Under the new legislation, buy-back companies were no longer required to provide directors' solvency declarations, auditors' reports on those declarations or for selective buy-backs an expert report on the integrity of the buy-back. The FCLSA legislation further allowed companies the flexibility to buy back more than 10 percent of their issued capital within twelve months for equal access, on market and selective buy-backs provided they obtain approval from their shareholders. ${ }^{5}$ For equal access and on-market buy-backs that are under the 10 percent limit no approval requirement is now necessary and the buy-back can be conducted almost immediately once the management has made the decision to do so and it is announced to the market. Given the legislative simplification and the fact that buy-backs are now less costly one would expect that buy-backs are more readily employed as a signaling tool.

Following the release of the FCLSA effective December 1995, there is a surge in the popularity of buy-backs (see table 1). From table 1 there is a dramatic increase in both the number and the dollar value of share buy-backs by Australian companies. Buy-back activity in 1997 and 1998 exceeded the $\mathrm{A} \$ 3.2$ billion amount mark or a greater than 12-fold increase on the A $\$ 272$ million figure for 1992, which was the highest yearly repurchase for the pre FCLSA period. Furthermore, in the 12-month period to June 1999, the financial press estimated buy-backs worth about $\mathrm{A} \$ 8.8$ billion were undertaken. In contrast with previous experience, over the more recent period the top 15 companies accounted for about 97 percent of the total buy-backs value. Clearly by 1999 buy-back activity was more prominent, undertaken by high profile companies and was entrenched as part of Australia's corporate culture.

5. An overview of the types of buy-back, the formal requirements of the legislation as well as the differences under the new FCLSA legislation are given in Mitchell and Robinson (1999) and Dharmawan and Mitchell (1999). 


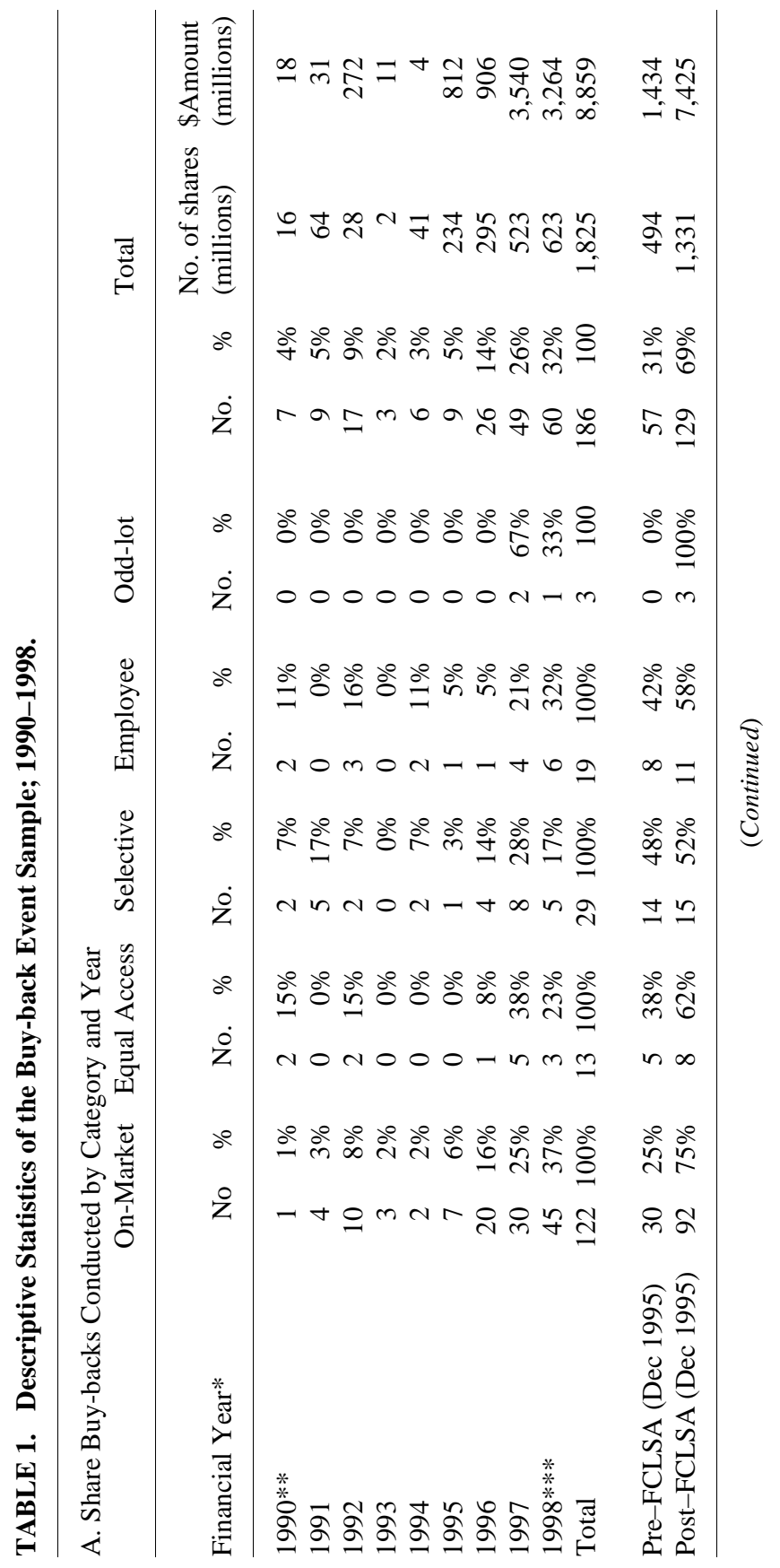




\section{Development of Research Questions}

A number of studies have examined the signaling of undervaluation motivation of buy-backs. Two major approaches are evident. The first looks at the abnormal share returns of buy-back companies around, prior to and after the buy-back event.

The initial Australian study by Harris and Ramsay (1995) examined just 16 buy-back announcements by companies over the period 1989 to 1993. Across all buy-back types they reported insignificant positive cumulative abnormal returns (CARs) of 4.1 percent around $(-5 /+5)$ the buy-back announcements. ${ }^{6}$ Equal access buy-backs generated the highest CARs of 8.4 and on-market 2.1 percent for the equivalent event window. A later study by Christianto, Clarke and Mitchell (1997) found the abnormal returns for on-market share buy-backs to be the highest, namely 2.5 percent over 11 -day $(-5 /+5)$ window but this again was not significant. Performance of the buy-back companies in the long-run was not conclusive. Generally the long-run performance was poor (negative CAR) but the magnitude differed depending on the benchmark against which the performance was measured. More recently, Lamba and Ramsay, (2000) documented a 5.0 percent response for on-market buy-backs for the $(-5 /+5)$ period after the December 1995 FCLSA implementation which is greater than that for the period prior (4.1 percent). Lamba and Ramsay (2000) suggest that the highly regulated regime prior to the FCLSA influenced the informational effects and market reaction and made on-market buy-backs less effective as a signaling mechanism. This finding was somewhat in contrast to the results of Balachandran and Troiano (2000). In addition, Balachandran and Troiano, (2000) found the announcement effect was stronger for initial on-market buy-backs ( 2.6 percent) but the later study of Otchere and Ross, (2002) does not.

In the U.S. originally, Stewart (1976) and more recently Ikenberry, Lakonishok and Vermaelen (1995) found that buy-back companies tend to perform better in the long run than non-buy-back companies. Further, Comment and Jarrell (1991) reported a negative correlation between announcement date returns and returns 40-days prior to the announcement. Stephens and Weisbach (1998) in the U.S. and Balachandran and Troiano (2000) for Australian data confirm this

6. The mean-adjusted model, the market-adjusted model and the risk-adjusted market model (CAPM) were used to measure abnormal returns. 
finding.

The positive market response can also be explained by the resolution of agency problems associated with having excess cash (Otchere and Ross, [2002]), tax benefits of the buy-back in lieu of dividends, and/or signaling of increased future payout/performance. Positive responses around or after the buy-back do not in themselves necessarily result from undervaluation. Hence, by studying the buy-backs of those firms that explicitly provide undervaluation as a reason, the experiment is sharpened and focuses directly on the area of interest, namely the link between the buy-back and the signaling of undervaluation.

The second common approach is to compare the undervaluation of buy-back companies relative to some benchmark group using a financial statement proxy such as the market-to-book or Tobin's-Q ratio (Ikenberry, Lakonishok and Vermaelen, [1995]; and Barth and Kasznik, [1999]). These undervaluation proxies are indirect, noisy measures with a variety of interpretations. For instance, some other common interpretations of the book to market ratio are investment/growth opportunities, a measure of market liquidity and/or related to unspecified risk factors (Fama and French, [1995]; and Barth and Kasznik, [1999]). One of the reasons market value typically exceeds book value is conservative accounting practices (Imhoff, [1988]) and an accounting system that fails to take into account many assets such as intangibles.

The capital market research from the U.S. (Dann, [1981]; Vermaelen, [1981]; Comment and Jarrell, [1991]; and Ikenberry, Lakonishok and Vermaelen, [1995]), Canada (Li and McNally, [1999]) and Australia (Harris and Ramsay, [1991]; Christianto, Clarke and Mitchell, [1997]; Balachandran, and Troiano, [2000]; Lamba and Ramsay, [2000]; Otchere and Ross, [2002]) found positive abnormal returns around and following the announcement of on-market share buy-backs. This previous research implies that buy-back companies are undervalued relative to their non-buy-back counterparts. Therefore, the first question is whether on-market buy-back companies are undervalued relative to the non-buy-back companies before the announcement. The second issue that is examined is do on-market buy-backs reduce information asymmetry and/or are they effective signals of undervaluation? If so, it is expected that the relative undervaluation will decline after the buy-back announcement.

On-market buy-backs are concentrated on for the following reasons. First, on-market buy-backs are the most prolific and the most topical in 
the financial press. Second, signaling of undervaluation is more appropriate and contentious for the on-market category. Finally, surveys of management of buy-back companies by Baker, Gallagher and Morgan (1981), Wansley, Lane and Sarkar (1989) and Tsetsekos, Kaufman and Gitman (1991) in the U.S. and Mitchell and Robinson (1999) and Mitchell, Dharmawan and Clarke (2001) in Australia note the strong support for the signaling of undervaluation motivation is primarily for on-market buy-backs.

Finally, other aspects that are considered are whether undervaluation is more predominant, for buy-backs after the FCLSA legislative change (Lamba and Harris, [2000]), for initial buy-back activity (Balachandran and Troiano, [2000]), or for those companies that specifically cite the motivation of undervaluation. Buy-backs that explicitly state that the underlying management motive is to signal undervaluation should have greater undervaluation prior to the buy-back and correspondingly, if the signaling is effective, a greater reduction in the undervaluation after the buy-back.

\section{Research Method and Data Sample}

\section{Method and Ohlson RIV Model}

Fundamental value, $V_{t}$, of the on-market buy-back companies is calculated using the Ohlson Residual Income Valuation (Ohlson RIV) model. ${ }^{7}$ Once calculated, the fundamental value, $V_{t}$ is then compared to the market value, $M_{t}$, and the $V_{t} / M_{t}$ metric determined. A buy-back company is deemed undervalued/overvalued in a relative sense if the ratio at the time of buy-back is greater/less than $V_{t} / M_{t}$ for the appropriate matched control company for the same time period. ${ }^{8}$ The matched control method is thus used to capture any widespread level of $V_{t} / M_{t}$ associated with similar companies at the same time period as the

7. For the reasons outlined in Ohlson (2001) the term and designation RIV is used rather than EBO, which refers to Edwards-Bell-Ohlson framework. More specifically, the Ohlson RIV model incorporates the appropriate and assumed linear information dynamics into the RIV model. Ohlson (2001) refers to it as EBD or the earnings, book value and dividends in the equity valuation model.

8. An absolute measure of undervaluation is also examined based on value of the $V_{t} / M_{t}$ metric relative to 1 . 
buy-back.

It is argued that the above approach provides a direct and alternative test of the undervaluation explanation for share buy-backs. It concentrates on identifying and assessing fundamental value and undervaluation specifically and it uses an accounting based valuation technique which, rather than relying on, complements market-based reactions. It is noted that this approach is naturally a joint test of both (i) the efficiency of the Ohlson RIV accounting based model and (ii) the signaling value of the buy-backs. The results thus need to be interpreted in such light.

The value of firm $V_{t}$ in the residual income valuation (RIV) model comprises two elements: ${ }^{9}$ (i) the book value of equity $\left(b_{t}\right)$ and (ii) the expectation of future abnormal earnings $\left(E_{t}\left[x_{t+i}^{a}\right]\right)$ where $\left(E_{t}\left[x_{t+i}^{a}\right]\right)=$ $E_{t}\left[x_{t+I}-r b_{t+I-1}\right]$ so that it can be expressed as:

$$
V_{t}=b_{t}+\sum_{i=1}^{\infty} \frac{E_{t}\left[x_{t+i}^{a}\right]}{(l+r)^{i}} .
$$

Where; $x_{t+i}=$ Net income or profit after tax and abnormal items in the $i^{\text {th }}$ period, $b_{t}=$ Book value of equity at time $t, r=$ Required rate of return or discount rate.

The Ohlson RIV model requires the time series of expected future abnormal earnings, $x_{t+i}^{a}$. The model relies on linear information dynamics (LID) to express the expected future abnormal earnings in terms of past abnormal earnings. The two LID equations are represented as:

Where:

$$
\begin{gathered}
x_{t+1}^{a}=\omega x_{t}^{a}+v_{t}+\mathcal{E}_{1, t+1} ; \\
v_{t+1}=\gamma v_{t}+\mathcal{E}_{2, t+1} .
\end{gathered}
$$

$v_{t}=$ Information other than abnormal earnings.

$\mathcal{\varepsilon}_{i, t}=$ Unpredictable, mean zero disturbance terms.

$\omega, \gamma=$ Fixed-persistence parameters that are non-negative and less than one.

Combining the LIDs in (2) and (3) with (1) leads to the following

9. Two assumptions are implied in the residual income valuation (RIV) model: one, value is equal to the present value of expected future dividends and two, clean surplus accounting. 
expression for $V_{t}$ :

$$
V_{t}=b_{t}+\alpha_{1} x_{t}^{a}+\alpha_{2} v_{t}
$$

And,

$$
\begin{gathered}
\alpha_{1}=\omega /(1+r-\omega) ; \\
\alpha_{2}=(1+r) /[(1+r-\omega)(1+r-\gamma)] .
\end{gathered}
$$

The term $v_{t}$ is the difference between the conditional expectation of abnormal earnings for period $t+1$ using all available information and the expectation of abnormal earnings based on current period abnormal earnings. This can be represented as: $v_{t}=E_{t}\left[x_{t+1}^{a}\right]-\omega x_{t}^{a}$. The period $t$ conditional forecast of the following period $t+1$ earnings is measured as the consensus analyst forecast of the period $t+1$ earnings, or $f_{t}$. The forecast of abnormal earnings based on all information is the forecast of earnings less the required rate of return on the book value of equity.

$$
E_{t}\left[x_{t+I}^{a}\right]=f_{t}^{a}-r \cdot b_{t}
$$

Other information, $v_{t}$, is then calculated as the difference between the forecast of abnormal earnings using all information and the expectation using only the historical abnormal earnings, namely:

$$
v_{t}=f_{t}^{a}-\omega x_{t}^{a}
$$

For some companies in the sample consensus analysts' forecasts are not available and accordingly $v_{t}$ is then assumed to be non-existent or zero. ${ }^{10}$ If the other information $v_{t}$ is zero, the effect is then that the third term in (4) is discarded and the value equation $V_{t}$ simplifies to:

$$
V_{t}=b_{t}+\alpha_{1} x_{t}^{a}
$$

Since the RIV model was introduced it has been used in a number of

10. In such instances as Ohlson (2001) notes this places a caveat on the empirical content of the model and this aspect of the current research. However, numerous and especially early studies using this approach have often simply made a general assumption of $v_{t}$ equal to zero (see Hand, [2001]). 
prominent empirical studies. ${ }^{11}$ Specifically the Ohlson RIV model is adopted here rather than the analyst forecast RIV model (Frankel and Lee, [1998]) that utilizes solely explicit forecasts of future earnings to determine future abnormal earnings. This is done for three main reasons. First, as noted by Dechow, Hutton and Sloan (1999) the Ohlson RIV model goes back to the original Ohlson (1995) formulation and assumptions of the model. Ohlson assumed that the time series behavior of abnormal earnings and other information were mean reverting and the autoregressive process thorough the LID captures this behavior. ${ }^{12}$ Previous empirical evidence (Dechow, Hutton and Sloan, [1999]) confirms that the mean reversion process observed in abnormal earnings is consistent with the Ohlson RIV framework. This is further reinforced in the results as presented in the next section. Second, benefits of using the Ohlson RIV are that it does not require explicit forecasts of dividends nor does it need an estimate of the "terminal value" component, which is an issue for the analyst forecast RIV model (Dechow, Hutton and Sloan, [1999]). Third, the Ohlson RIV model allows for the role of "other" information and expected earnings in the analysis in conjunction with historical earnings. Hence, where available, analyst forecasts are used as a means of identifying the "other" information in the model. However, analyst forecasts data available on $\mathrm{I} / \mathrm{B} / \mathrm{E} / \mathrm{S}$ is restricted to some of the more prominent Australian companies so this confines the analysis. ${ }^{13}$

One point of note is that most of the previous studies above largely examine the ability of the Ohlson or RIV model to explain share prices and/or expected returns. In contrast, for this study, as in Lee, Myers and Swaminathan (1999) the model to estimate fundamental value is used with the view that price can deviate from fundamental value.

11. Examples include Penman and Sougiannis (1998), Frankel and Lee (1998), Dechow, Hutton and Sloan (1999), Lee, Myers and Swaminathan. (1999) and Francis, Olsson and Oswald (2000).

12. For a good overview of the RIV model including the difference between the Ohlson RIV and analysts' forecast RIV versions as well as their empirical implications see Dechow, Hutton and Sloan (1999) and Ohlson (2001).

13. Fifty-five of the 186 buy-back events identified had analysts' forecast data available on I/B/E/S and/or BARCEP the Australian equivalent. Similarly 62 of the 186 non-buy-back control group had analysts' forecasts. In total there are some 819 analyst forecast observations or on average about 7 observations per buy-back or control event. Interestingly, the inclusion of the analyst forecast data, as other information, does not qualitatively change the results obtained. 
Sample Selection

The historical earnings and necessary financial inputs needed to estimate the fundamental value or $V_{t}$ are obtained from the financial statements immediately prior to the buy-back announcement date. On average the release date is about three months after the actual balance sheet date. ${ }^{14}$ Hence the valuation $V_{t}$ is seen as available and measured as at the release date of the financial statement information when the preliminary earnings/financial data are disclosed to the market. Market value $\left(M_{t}\right)$ is correspondingly measured at the same point in time to ensure that both $V_{t}$ and $M_{t}$ are synchronous in terms of information content. Market value $M_{t}$ is determined on a total company basis and is the number of outstanding shares multiplied by the share price at the time of valuation. The $V_{t} / M_{t}$ metric immediately prior to the buy-back announcement date is referred to as the $V_{t} / M_{t}$ metric for period 0 . Similarly, the $V_{t} / M_{t}$ metric for the two accounting periods prior to the initial annual report date and the two periods after are denoted as periods $-2 /+2$, respectively.

The sample includes all share buy-backs by listed Australian companies from the time buy-backs were initially permitted in November 1989 until 30 June 1998. The sample excludes preference share buy-backs and share buy-backs by listed trusts as these do not convey the same signaling aspects associated with ordinary shares. The data on share buy-back announcements were obtained from the Signal G ASX electronic company announcements and ASX data disk information sets. In total, 186 buy-backs conducted by 119 listed companies were identified over the sample period. There are 122 on-market buy-backs.

Financial variables were collected from the Company Analysis database, ASX data disk, Australian Graduate School of Management Annual Report Microfiche, and Annual Reports lodged with the ASIC. The control sample or non-buy-back companies were matched on a one-to-one basis. This control event group is selected based on three criteria; (i) The company has the same three-digit ASX industry code as the matched-buy-back company, (ii) The control is the closest match to the buy-back company in terms of market capitalization at the time of the buy-back announcement, (iii) The control company annual reports

14. The ASX requires listed companies to release preliminary final reports within 75 days of balance sheet date. 
for the study period must be available on one of the above databases so that the financial variables can be sourced from the same year (event period) as the matched buy-back companies. The matching of the control sample by ASX industry code and market capitalization controls for both industry and size effects, respectively. The market capitalization, assets and book-to-market ratio of the buy-back samples are not significantly different from the control sample confirming the success of the matching process.

\section{Descriptive Statistics of the Sample}

Table 1 provides the descriptive statistics of the sample. The different types and the number and dollar values of buy-backs over the period 1990 - 1998 are displayed in table 1 panel A. One observation is the number and dollar values have increased significantly over time and especially since the introduction of the FCLSA. Total dollar value of buy-backs is just over A $\$ 1.4$ billion for the pre FCLSA $(1990$ - 1995) period whereas it is over A $\$ 7.4$ billion in the post FCLSA (1996 1998) period. From table 1 panel A the most common form of buy-back is the on-market type, which constitutes 66 percent of the total buy-back activity over the sample period.

Examinations of the motivations lodged with the ASX (table 1 panel B) reveals "signaling of undervaluation" to be the main motivation for on-market buy-backs (41 percent of instances). Some companies provide more than one motivation so there are more "motivations" than buy-back events. Not surprisingly, selective buy-backs are motivated by the intention to remove shareholders and to restructure capital, whereas employee buy-backs are mainly used to provide liquidity to these shareholders. Finally, the dominant motivations for conducting equal access buy-backs are tax savings for shareholders and signaling. The motivation of the differential tax treatments of equal access buy-backs is perfectly understandable as the competing activity of special dividends distributes funds in an equivalent manner but has an alternative tax treatment. Overall, the motivations noted in table 1 are consistent with previous Australian findings by Mitchell and Robinson (1999) and Mitchell, Dharmawan and Clarke (2001) and demonstrates the appropriate focus of the undervaluation tests is in relation to the on-market buy-back category.

Another point evident from table 1 panel $\mathrm{B}$ is that a substantial number of companies failed to provide (unknown or not available) 
motivations for their on-market buy-backs. This is surprising, especially post the FCLSA period as the ASX listing rule 7.29 (effective 1 July 1996) required them to disclose such information in the Appendix 7B notice - Announcement/variation of on-market buy-back.

\section{Estimates of Parameter Inputs}

The $r, \omega$ and $\gamma$ parameters need to be estimated for the model inputs. There are many ways of estimating the required/expected rate of return $r$. In previous studies, the measures of $r$ have generally been based on historical estimates of either the accounting rate of return itself or capital market estimates of $r$ obtained from models that use historical market data. For instance, Dechow, Hutton and Sloan (1999) simply use the long-run historical average market return on U.S. equities estimated at 12 percent. Others, such as Frankel and Lee (1998), Lee, Myers and Swaminathan (1999) and Francis, Olsson and Oswald (2000), use time-varying industry and/or market based discount rates derived from either the CAPM, or three-factor Fama-French, models (see Fama and French, [1997]). Abarbanell and Bernard (2000) calculate $r$ using an individual company-specific systematic risk CAPM approach. For these models the systematic beta component(s) as well as the expected market premiums are based on estimates using historical share market data. Finally, Lee et al. (1998) take a different tack and use historical long-run adjusted accounting return on equity $(\mathrm{RoE})$ as an unbiased proxy measure of $r$.

Following Dechow, Hutton and Sloan the view here is that the objective is not to evaluate the alternative methods of arriving at $r$. This is because first there is little consensus on how $r$ should be estimated. Second, studies such as Dechow, Hutton and Sloan (1999), Frankel and Lee (1998) and Abarbanell and Bernard (2000) find that the choice of $r$ and whether it is assumed as either constant or calculated on a specific individual firm basis has little influence on results. ${ }^{15}$ However, given the

15. In order to consider the potential sensitivity of the results $r$ is estimated for the sample using alternative approaches. Markets based-methods using (i) firm-specific cost of equity derived using the CAPM; (ii) an industry based discount rate using a single factor CAPM model and (iii) a time-varying discount rate based on a consistent market premium, are all used. In each case the individual as well as the aggregate pooled value of $r$ obtained is reasonably consistent and leads to very similar findings as that provided in table 3 panel A for the historical RoE method. These alternative methods for $r$, as well as varying the input values for each of the methods, lead to similar findings as the undervaluation results presented in later tables. In short, the above analysis allows us to conclude that, the approach of 
empirical focus on individual firms $r$ is estimated separately and individually for each event period. This approach captures the specific risk and other characteristics of each firm.

The approach to estimating $r$ is the average historical adjusted accounting return on equity. ${ }^{16}$ First, the raw historical RoEs are calculated over the 10-year period prior to the buy-back announcement or control event period. Second, the historical RoEs are then adjusted by trimming the few extreme observations that distort and unduly influence the RoE distribution and statistics. Similarly, there are a few cases of negative book values of equity, which are also considered as outliers and removed. ${ }^{17}$ Finally, in isolated cases where the average firm-specific RoE is negative, this is substituted by the historical median figure of RoE. The above adjustment enables us to derive a distribution of RoEs that (i) can forecast $r$, (ii) satisfies the positive condition and (iii) are an unbiased estimate of $r$ for companies and events.

Estimates of $r$ are given in table 2 panel A. The pooled estimate of $r$ based on the adjusted historical RoEs is 11.3 percent. This is very similar to the mean of the individual firm specific estimates of $r$ of 11.2 percent. A small difference between the pooled estimate of $r$ for the buy-back group (11.0 percent) and the non-buy-back sample (11.5 percent) occurs although this difference is not significant. There is variation of $r$, as evident in the standard deviations for each sample, which are in excess of 5.1 percent. The variation in $r$ is consistent with out approach of estimating $r$ separately for each firm and event $(r=$ $\left.R o E_{i}\right)$.

Table 2 panel B provides adjusted firm specific estimates as well as pooled estimates of the first order auto correlation coefficient of abnormal earnings $\omega_{1}$. It is emphasized that all calculations of the

controlling for risk and estimating $r$ has little impact either on $r$ or the undervaluation results obtained.

16. The average RoE of the company over the 10 -year period is seen as a reasonably good and unbiased proxy for the ex ante firm specific rate of return on equity. Evidence suggests that this is the case. The average RoE for U.S. firms over the period 1976-1993 is estimated at 13 percent (Frankel and Le, [1998]), which is similar to the documented historical market equity returns (see Dechow, Hutton and Sloan [1999] and Francis, Olsson and Oswald [2000]).

17. The process and adjustments to the historical RoEs are formally as follows: (i) exclude any observations with negative equity. (ii) Remove any extreme observations where RoE is greater than $+/-50$ percent. (iii) Winsorize remaining observations that are greater than $+3 /-3$ standard deviations away from the median. 


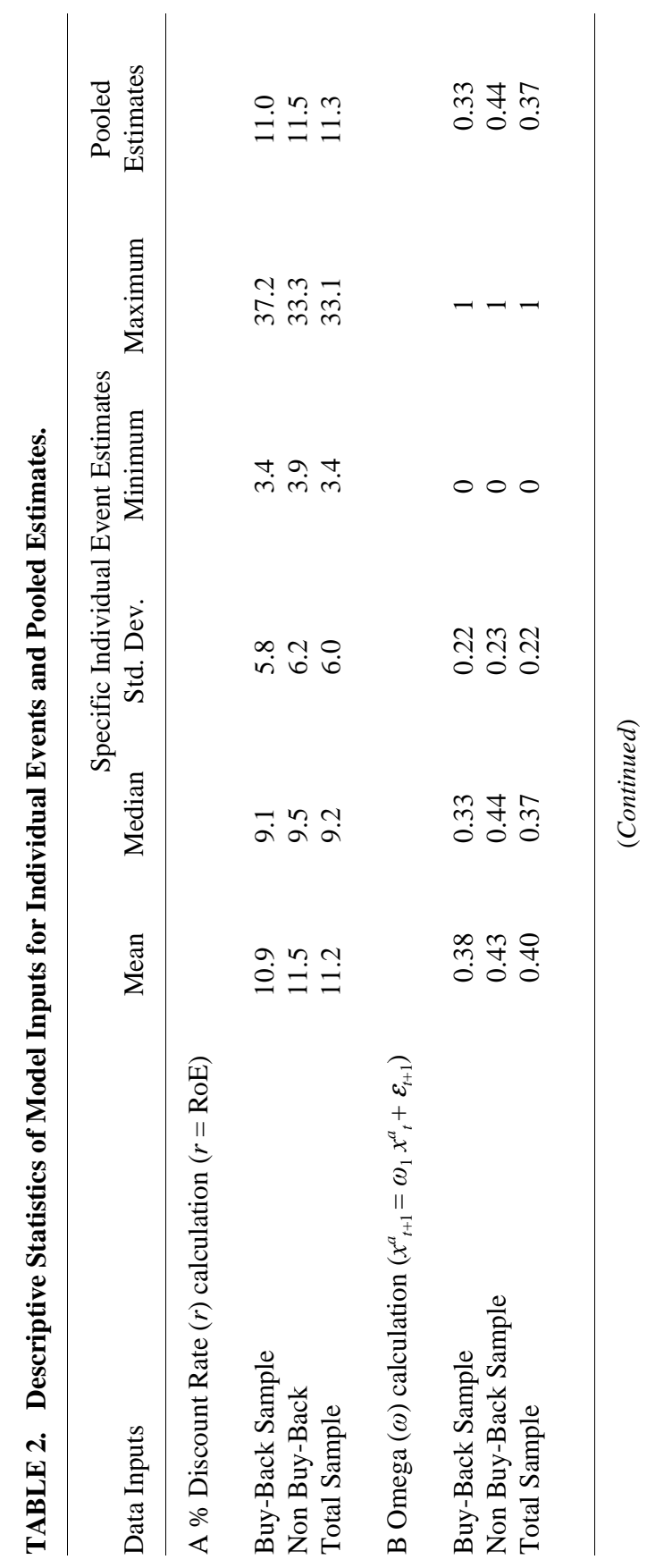




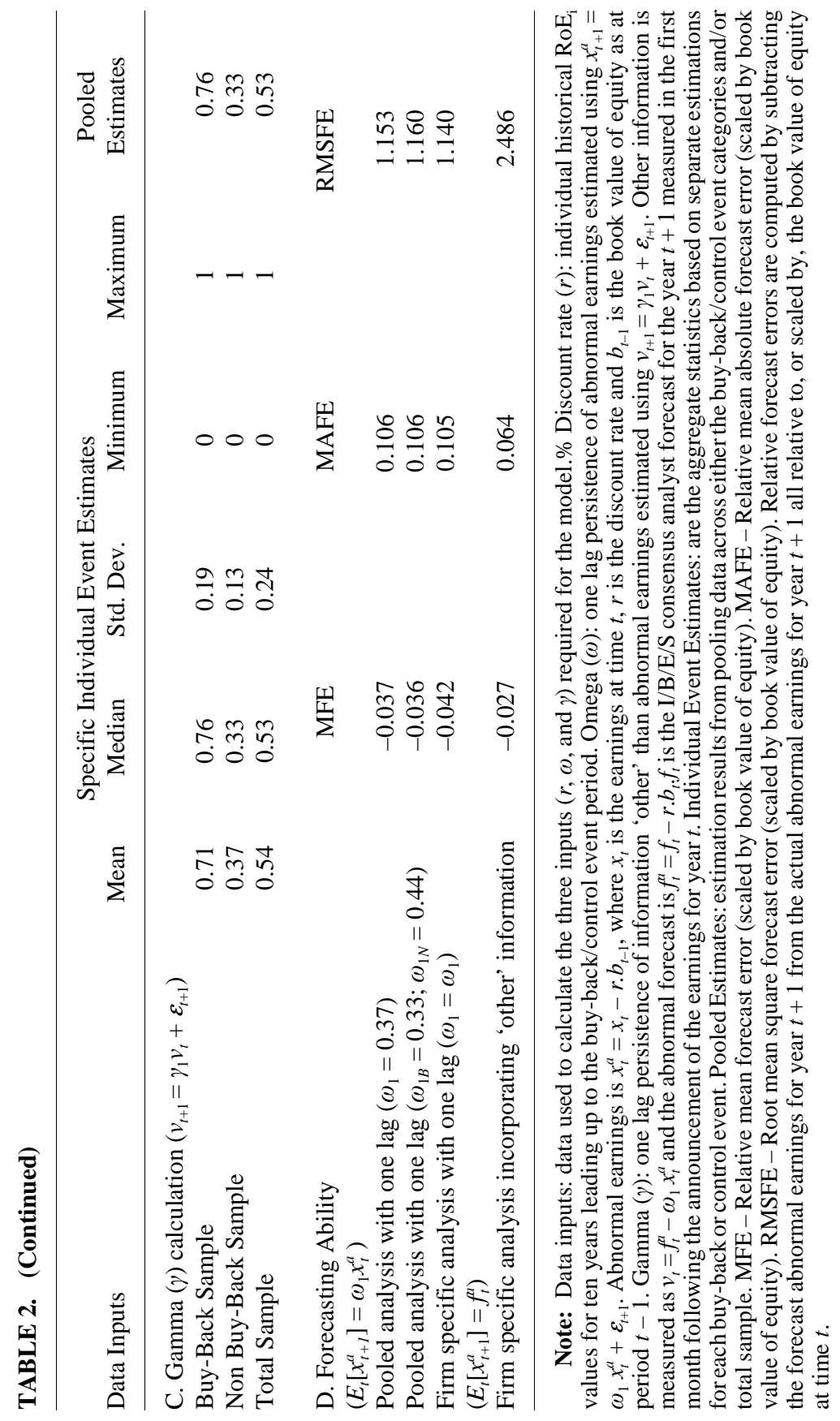


abnormal earnings and hence $\omega_{1}$ use individual estimates of $r$ and are computed for the full ten-year period prior to the buy-back. Estimates are obtained for the pooled sample as well as for the buy-back and non-buy-back samples. The overall pooled $\omega_{1}$ (shown in the last column of table 2 panel B) for the total sample is 0.37 and varies considerably and significantly between the buy-back (0.33) and the non-buy-back sample (0.44).

Firm specific estimates of $\omega_{1}$ are calculated by conducting separate auto correlations for each buy-back or control event. The individual $\omega_{1}$ were then modified to ensure that they lie between 0 and 1 as specified in Ohlson (1995). As a result, where negative values of $\omega_{1}$ occur or where it was not possible to calculate $\omega_{1}$ because of missing or insufficient data they are replaced by the pooled estimate. Given the variation in $\omega_{1}$, both individual and pooled estimates of $\omega_{1}$ are used in the subsequent investigation of the forecasting ability.

The estimate of $\gamma_{1}$ is contained in table 2 panel C. There is a vast difference in $\gamma_{1}$ for the buy-back relative to the non buy-back sample. The non-buy-back median and pooled estimate for $\gamma_{1}$ of 0.33 is in line with previous U.S. studies (0.32 in Dechow, Hutton and Sloan, [1999]) however the buy-back sample estimate of 0.76 , is not. Given the substantial difference between, and the variation within, the buy-back and non-buy-samples it is expected that the use of individual estimates of $\gamma_{1}$ should improve the accuracy of forecasting future abnormal earnings.

\section{Forecasting ability}

The effect that different values of $\omega_{1}$ have on forecast accuracy is now briefly determined.$^{18}$ All forecast errors are computed by subtracting the forecast of abnormal earnings at $t$ from the actual abnormal earnings at year $t$. The relative forecast errors are then computed by deflating the forecast errors by the book value of equity at year $t$. Table 2 panel D evaluates the relative forecast error of abnormal earnings based on different parameter values for $\omega_{1}$. First, the pooled estimate across groups - which uses a constant $\omega_{1}$ value of 0.33 for the buy-back group and 0.44 for the non-buy-back group $\left(\omega_{1 B}=0.33 ; \omega_{1 N}=0.44\right)$. Second,

18. The subscript is introduced to highlight that it is a first-order correlation coefficient. There are 2983 observations over the total of 372 events or approximately an average of 8 years of observations per event. 
pooling $\omega_{1}$ across the total sample $\left(\omega_{1}=0.37\right)$ and third the individual estimation approach where $\omega_{1}$ is estimated separately for each event $\left(\omega_{1}\right.$ $\left.=\omega_{i}\right)$. The pooled estimate across groups is the most unbiased as it has the lowest mean forecast error (MFE) of -0.036 . It is slightly superior to pooling across the total sample $(-0.037)$ and separate individual estimation (-0.042). In all cases MFE are negative as on average actual abnormal earnings are less than the forecasted abnormal earnings.

Table 2 panel D provides the forecast error using the analysts forecast with the firm specific analysis, which can be compared to the individual historical abnormal earnings estimates. The MFE is closer to zero for the consensus analyst forecast $(-0.027)$ reflecting a reduction in the amount of bias noted earlier $(-0.042)$. Some bias still remains though, and on average analysts' forecasts are still overly optimistic. In addition, the analyst forecasts are on average more accurate as evident by the substantial reduction in the MAFE from 0.105 to $0.064 .{ }^{19}$

In summary, the findings indicate that the abnormal earnings are well described by the LID of the Ohlson model. The estimated auto regressive parameters $\left(\omega_{1}, \gamma_{1}\right)$ are significantly different from 0,1 and a first order auto regression process appropriately approximates the abnormal income and other information. The inclusion of analyst forecasts seems to add to the forecasting ability as they reduce bias and improve overall accuracy of the forecasts of future abnormal income. Coupled with the above a substantial variation within and between the buy-back and non-buy-back samples is documented for all the input parameters. As the focus is on individual firms and events, the fundamental value $V_{t}$ in each instance is estimated using the Ohlson model (i) incorporating other information $v_{t}$ and (ii) with the individual firm and event specific inputs estimated for the $r, \omega_{1}$ and $\gamma_{1}$ parameters. $^{20}$

19. One caveat here is that there are several instances where the forecasts are very inaccurate. Most often ( 21 out of the top 30 forecast errors) this involves the situation where the company eventually posts a large abnormal loss although the analysts are repeatedly forecasting a healthy abnormal profit or a small abnormal loss. This error is exacerbated under the RMSFE criterion as these extreme forecast errors are then weighted very heavily. The RMSFE forecast error of 2.486 is a direct result of this and is substantially greater for the analyst forecast approach in contrast to the 1.140 under the historical abnormal earnings approach.

20. The sensitivity of the $V_{t} / M_{t}$ metrics and hence undervaluation results to misspecification of the $r, \omega_{1}$ and $\gamma_{1}$ was extensively tested. Individual variations up to $\pm 2 \%$ in $r, \pm 0.10$ in $\omega_{1}$ and $\gamma_{1}$ holding the other estimation parameters and inputs constant does not change the results obtained either quantitatively or qualitatively. 


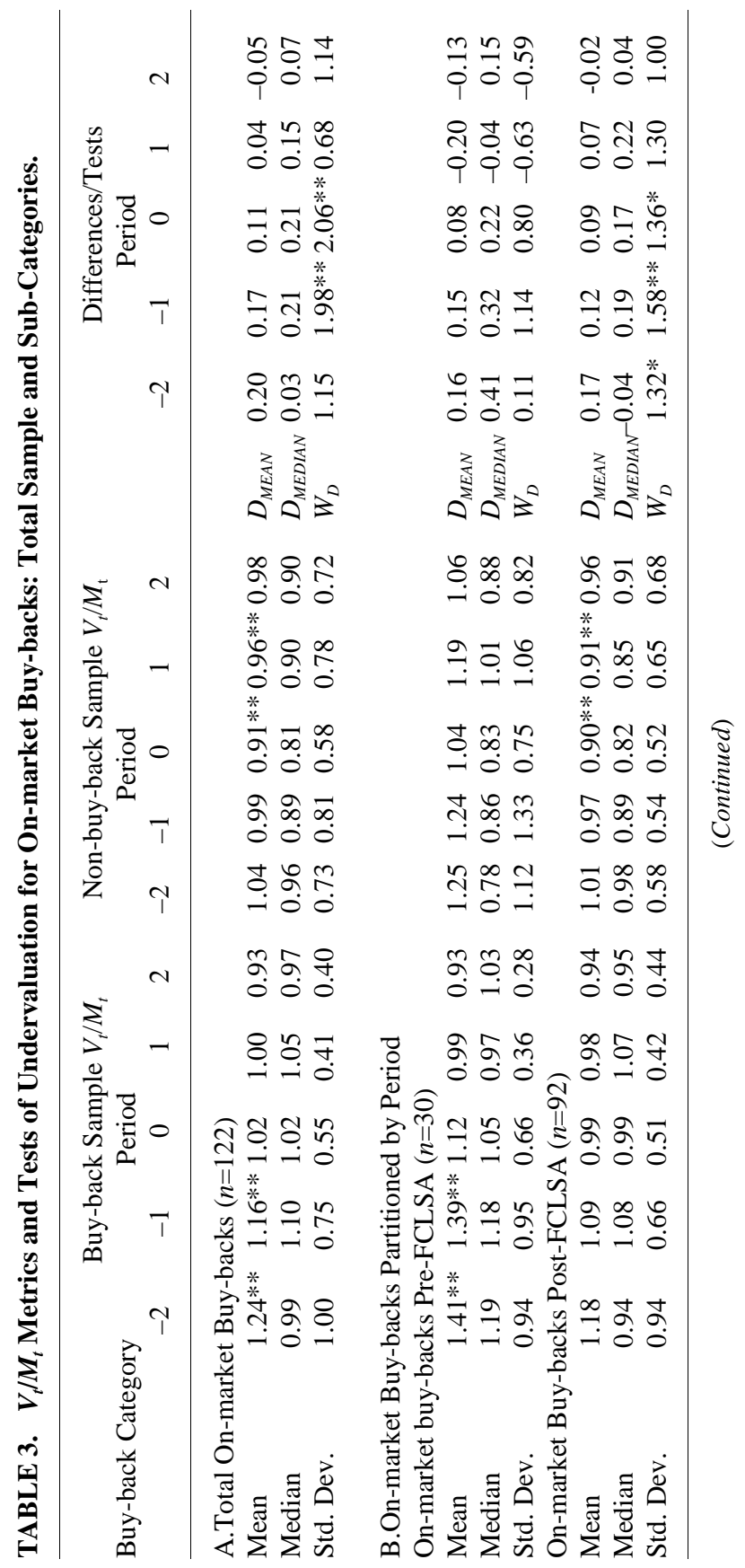




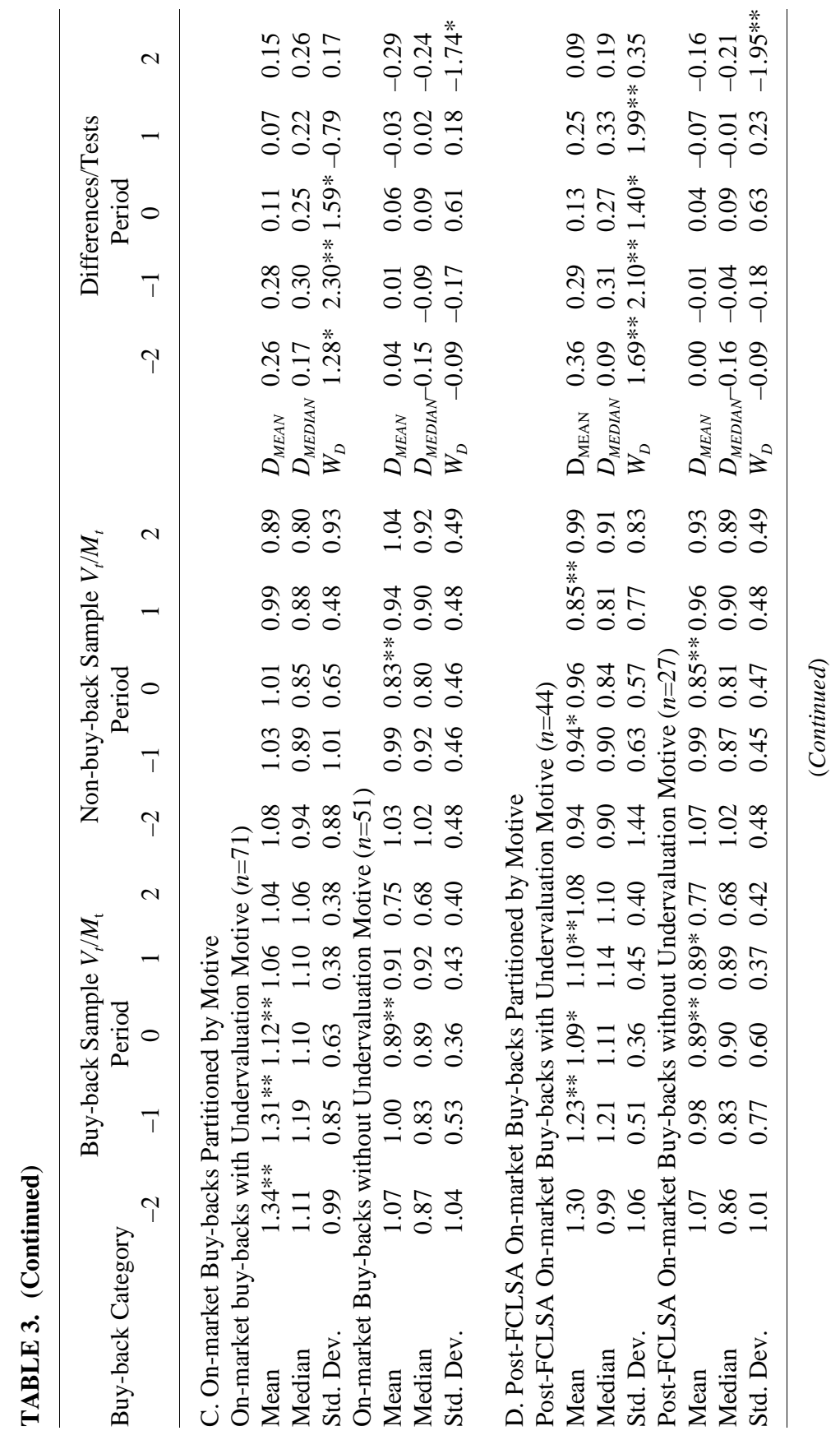




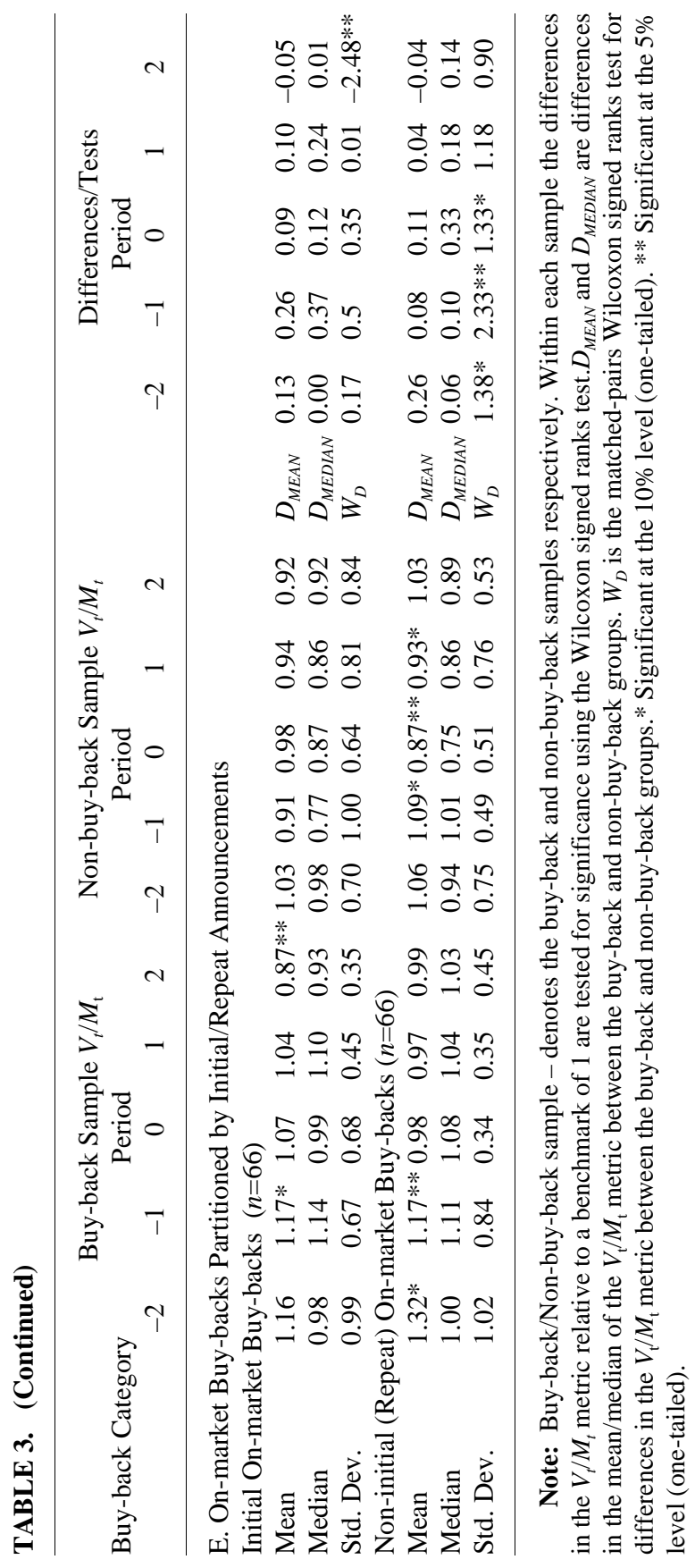




\section{Main Findings}

\section{Are Companies that Conduct On-market Buy-backs Undervalued?}

The $V_{t} / M_{t}$ metrics for both the on-market buy-backs and control samples are given in table 3 panel $\mathrm{A}$ for the period $-2 /+2$, where period 0 is the period immediately prior to the buy-back event. The focus here is on on-market buy-backs as the signaling of undervaluation is mainly used as a motivation in that context. ${ }^{21}$

From table 3 panel A the on-market buy-back group has high undervaluation in the periods leading up to the buy-back. This undervaluation is significantly different to the control group over the last two periods before the buy-back. As both the $V_{t} / M_{t}$ data and differences are non-normal, tests for significant differences in the distribution between the buy-back and the non-buyback sample are conducted using the non-parametric Wilcoxon-Signed-Rank matched-pairs test $\left(W_{D}\right)$.

The mean/median undervaluation estimate for the buy-back group is high both in absolute and relative terms and is more accentuated in the periods prior to the on-market buy-back announcement. The undervaluation at period -2 is 0.20 and then reduces steadily but does not totally disappear and is still significant in the period immediately prior to the buy-back (0.11 at period 0$)$. Prior to the announcement (period -2/0) it is observed that buy-back companies are significantly undervalued relative to the control sample, which suggests that at least some on-market buy-backs signal undervaluation. Part of the undervaluation is already removed at the financial statement date immediately prior to the buy-back. The $V_{t} / M_{t}$ metric for the buy-back sample reduces from 1.24 at period -2 to 1.02 at period 0 . Further, the difference in the $V_{t} / M_{t}$ relative to the control group narrows accordingly.

The significant undervaluation immediately prior to the on-market buy-back ( 0.11 in period 0 table 3 , panel A) is reduced after the buy-back announcement (0.04) but the full undervaluation is not removed instantaneously and is only totally removed by period +2

21. As expected the extent of undervaluation and thus the degree of signaling as evident by the change in undervaluation across the periods are almost universally located in the on-market buy-back category. The equal access buy-backs have some degree of undervaluation prior to the buy-back but this is not significant. The selective, employee and odd-lot buy-backs show no evidence of systematic undervaluation - either in absolute or relative terms. Only the on-market results are thus reported. 
$(-0.05)$ when it becomes negative or overvaluation. Hence, some undervaluation albeit insignificant does persist in period +1 , suggesting that not all the undervaluation is traded out immediately.

\section{Legislative Changes and Motivation of the On-market Buy-back}

If the estimate of undervaluation is more pronounced for companies that specifically note undervaluation as a motive, then a larger reduction in undervaluation is expected. Further, it has been suggested that one of the prime purposes of the FCLSA legislative amendments was to simplify the process so that buy-backs can proceed with less restrictions, legal costs and complexity. This may well have resulted in companies utilizing buy-backs more readily as a means to signal undervaluation more credibly (Lamba and Ramsay, [2000]). Buy-backs, however, are a more costly signal compared with other forms of signaling such as dividends, stock splits, management earnings forecasts and other information releases (Asquith and Mullins, [1986]). Consequently, it is expected that more firms will utilize buy-backs in the post FCLSA period as a means to counter undervaluation.

Table 3 panel B partitions the sample of on-market buy-backs into pre- and post-FCLSA, and panel $\mathrm{C}$ by the motive - whether the motivation provided was "to signal undervaluation" or not. First, the estimate of undervaluation is definitely more pronounced for the post-FCLSA in contrast with the pre-FCLSA period. Second, the signaling mechanism seems to work effectively in most cases as the undervaluation measure is not significant after the buy-back although some undervaluation does remain (table 3 panels B and C). Results therefore suggest that post the FCLSA on-market buy-backs are more effective and credible as a signaling mechanism. This inference is in line with the increased abnormal returns over the post-FCLSA period documented by Lamba and Ramsay (2000).

Table 3 panel $\mathrm{C}$ shows that almost all the estimated undervaluation occurs where management provides undervaluation as a reason in the buy-back announcement. The post-FCLSA period is naturally the period ultimately of most interest. In table 3 panel D the post-FCLSA period is further partitioned by the undervaluation motive and similar results as for the whole period are found and noted in table 3 panel $\mathrm{C}$. However, for the post-FCLSA environment, and where undervaluation was explicitly stated as a motive, significant undervaluation persists for one period after the buy-back. In this instance the persistence of the 
undervaluation may be one of the reasons that studies such as Ikenberry, Lakonishok and Vermaelen (1995) have documented long-term gains from investing in buy-back companies. The gains and market reaction are not captured immediately and companies continue to perform well into the future and/or the market price takes a while to adjust. An alternative explanation here is that the market adjusts to existing undervaluation but that additional undervaluation appears by the next period.

It is observed that some buy-back companies become overvalued in period 2. However, the overvaluation is significant only in instances where undervaluation is not stated as a motivation, for both the pre- and post-FCLSA periods. It is also evident for initial buy-backs, where again there is little evidence of undervaluation. One possible explanation is that it is an overcorrecting mechanism by the market - after it has fully absorbed there was no undervaluation associated with the buy-back. Another alternative explanation is that it is due to omitted variables not captured in the forecasted information or "other" information variable used in the Ohlson model.

\section{Initial vs. Subsequent On-market Buy-backs}

The argument is that the undervaluation for buy-back companies would be more pronounced for initial relative to subsequent buy-backs. This is for two reasons. (i) As the market becomes accustomed to buy-backs the signaling power will be reduced. (ii) Some subsequent buy-backs are effectively extensions of an existing scheme so the market reaction and signaling implications will be consequently reduced (Balachandran and Troiano, [2000]). The results in table 3 panel E reveal the opposite; undervaluation is more pronounced during subsequent buy-backs. ${ }^{22}$

Potential explanations for the unexpected results here are twofold. First, the effect is related to the extent of the undervaluation motive noted above, as well as a learning curve effect on the part of firms. Firms eventually discover that they are more likely to convince the market that there is undervaluation and get a favorable market response when they actually have and state undervaluation as a motive. Second, many of the initial buy-backs were conducted earlier in the pre-FCLSA sample period where the market familiarity with buy-backs is lower and the response is not so pronounced. The results agree with Otchere and

22. This is mainly located in the post-FCLSA period. 
Ross (2002) who found that the initial buy-back had less of a market response and conveys less information content relative to repeat buy-backs.

\section{General Discussion and Implications}

There are a number of general implications from the results in table 3. The results support that if a company conducts a buy-back, then it is more likely to be undervalued relative to similar companies that do not conduct a buy-back. In the context of the Australian stock market the results imply that buy-backs are an effective mechanism for signaling undervaluation. This is despite other potential signaling mechanisms such as dividends, pro-forma statements, management earnings forecasts and other information releases. As pointed out by Asquith and Mullins (1986), the buy-back has distinct signaling properties relative to all these information releases. One caveat here is that the absence of surplus cash, the increased agency costs of debt and the tax effects of the buy-back distribution may all prohibit a potential repurchase. Therefore it is feasible that undervaluation remains even though management can identify it.

In table 3 a control group method is used to capture any undervaluation that may be common across firms in the market. Further, in table 3 tests of the undervaluation of $V_{t} / M_{t}$ relative to unity or an absolute benchmark are included. This is done using the one-sample Wilcoxon signed ranks test of differences in the distribution of the data relative to one. The significance levels for the tests are indicated in the table. In a number of instances the non-buy-back sample is overvalued relative to the absolute benchmark of one. This is primarily evident for the total on-market control group (panel A) as well the buy-back control group post the FCLSA (panel B) and the repeat buy-backs (panel E). To examine whether these later results reflect random shifts in the market values or systematic overvaluation, the results were averaged over longer periods for the various samples. For the non-buy back control sample, the average $V_{t} / M_{t}$ over the five $(-2 /+2)$ periods is 0.99 and for the total (combined buy-back and control) sample it is 1.03 , both of which are insignificantly different to one. The buy-back sample has an average of 1.08 , over the five $(-2 /+2)$ periods, which is significantly different from one and reflects the undervaluation evident in the pre-buy-back period $(-2 / 0)$. 


\section{Cross-sectional Determinants of Undervaluation}

In addition to the motivation and other institutional factors above, some cross-sectional tests were conducted in an attempt to see whether the undervaluation is related to specific company and/or buy-back attributes. First, to the extent that the book-to-market ratio is a reasonable proxy for undervaluation (Ikenberry, Lakonishok and Vermaelen, [1995] and Barth and Kasznik, [1999]), a direct relationship between this ratio and the undervaluation metric is expected. The book-to-market ratio (BkMkt) is measured as the book value relative to the market value of equity. Second, larger companies have a greater analyst following, receive greater media attention and generally choose to disclose more of both financial and non-financial information. Hence, for smaller firms there is a greater amount of asymmetrical information between managers and shareholders, and consequently more undervaluation. Here size, measured by the natural log of the market value of equity (MktCap), is seen as a proxy for the amount of information release (Vermaelen, [1981]; Pugh and Jahera, [1990]).

Another conjecture is that undervaluation prior to a repurchase will be inversely related to the amount, or percentage of institutional ownership in the firm as Information asymmetry is higher the lower the level of institutional holdings (Ratner, Szewczyk and Tsetsekos, [1996]). Institutional holdings (InstHld) are measured by the percentage of shares held by institutions relative to the total. Conversely, companies with a higher proportion of management/directors' share ownership (DirHld) are likely to provide a more credible a signal, than companies with a lower proportion of management share ownership (Vermaelen, [1981]; and Comment and Jarrell, [1991]). The extent of undervaluation should be positively related to the percentage of the directors' share ownership. Finally, the size of the buy-back itself is a powerful signal of management's belief in the company as it is backed by a cash payment (Asquith and Mullins, [1986]) and signals a greater belief in the potential undervaluation (Comment and Jarrell, [1991]; Liu and Ziebart, [1997]; Stephens and Weisbach, [1998]). The relative size of the buy-back is measured as the proportion of the number of shares actually bought back relative to the number of shares on issue (BBPerc).

In the univariate tests, the sample is initially partitioned into two halves: the upper and lower half of the distribution divided on the median value of the relevant attribute/independent variables (BkMkt, Size etc.) measured in the period immediately prior to the buy-back 


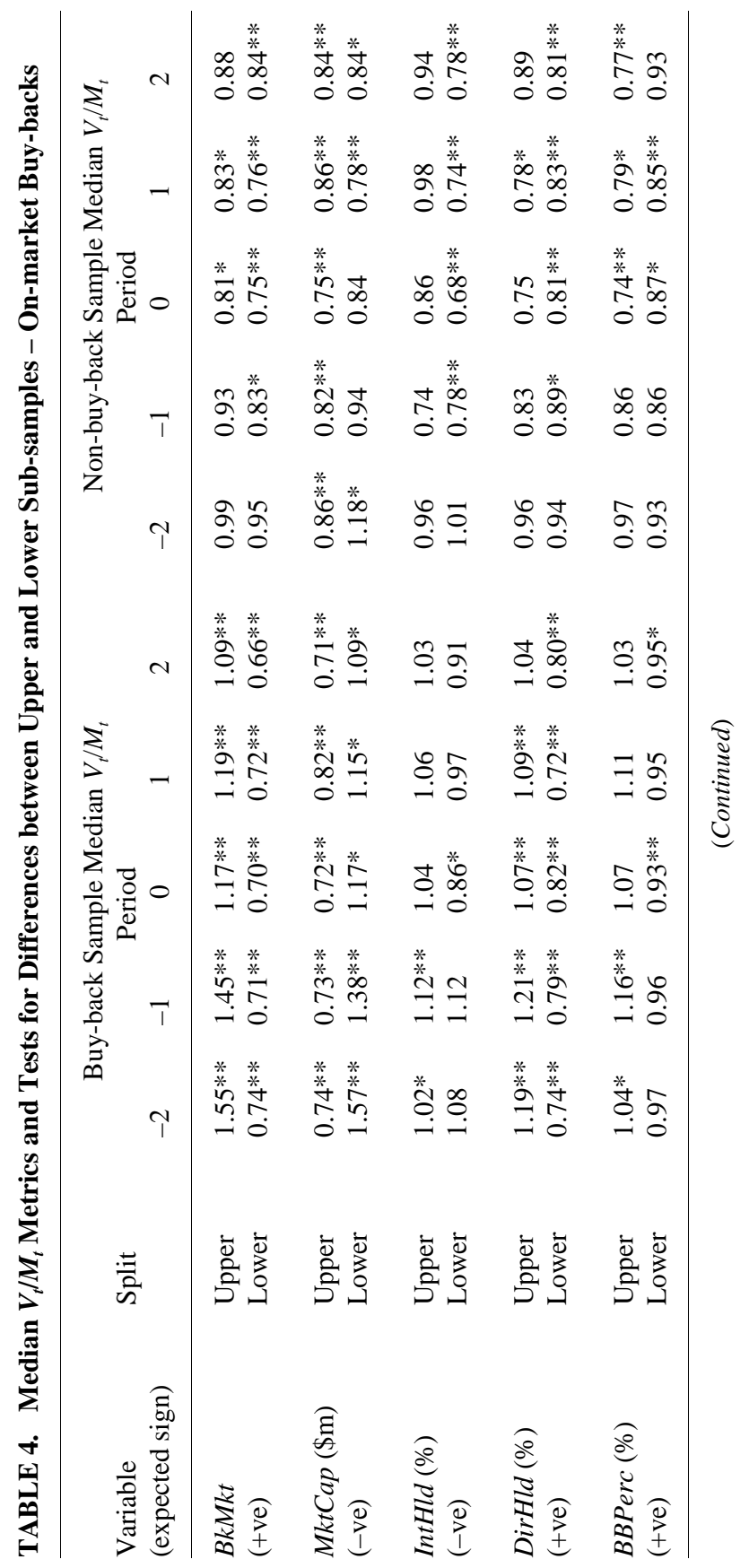




\section{On-Market Buy-Backs}

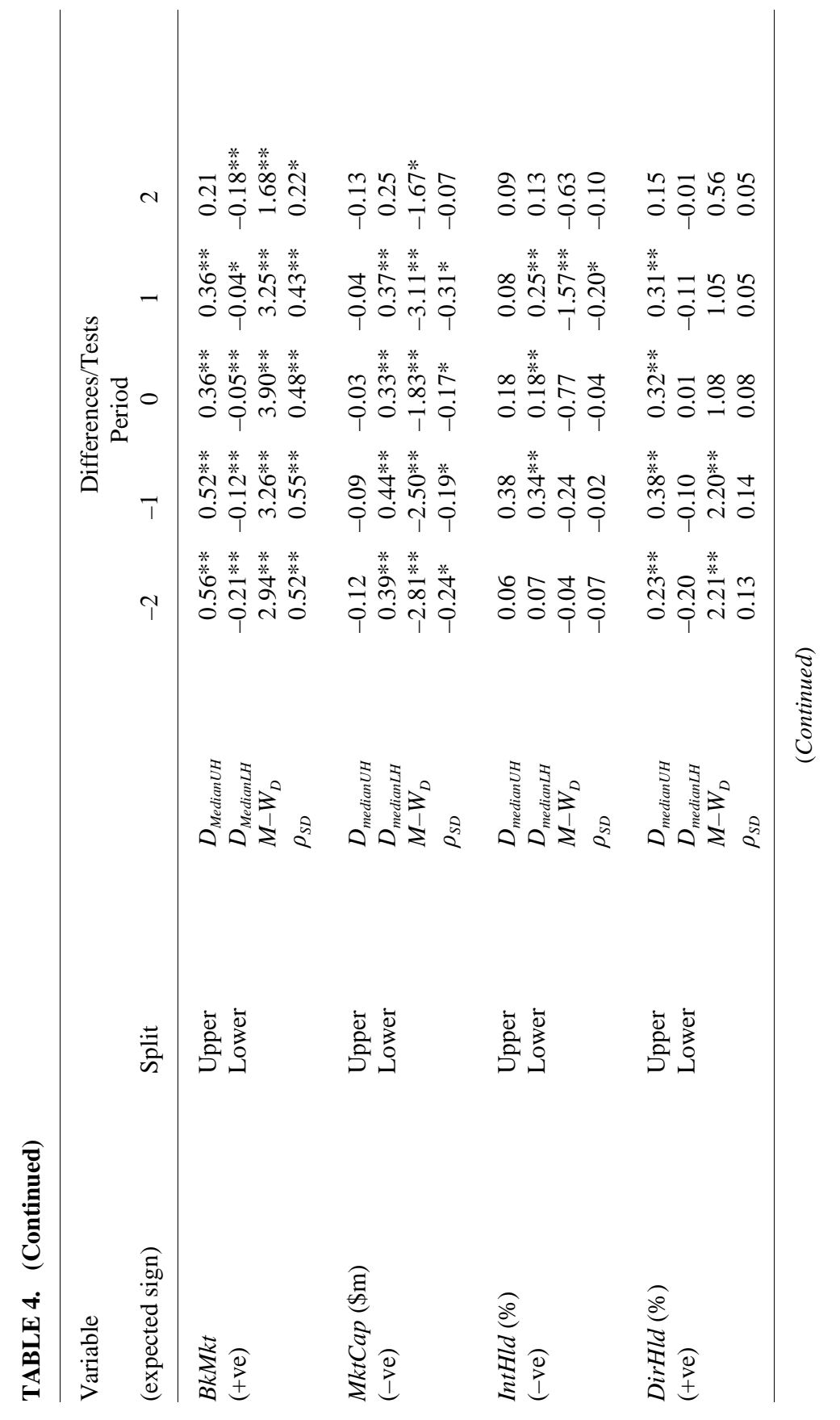




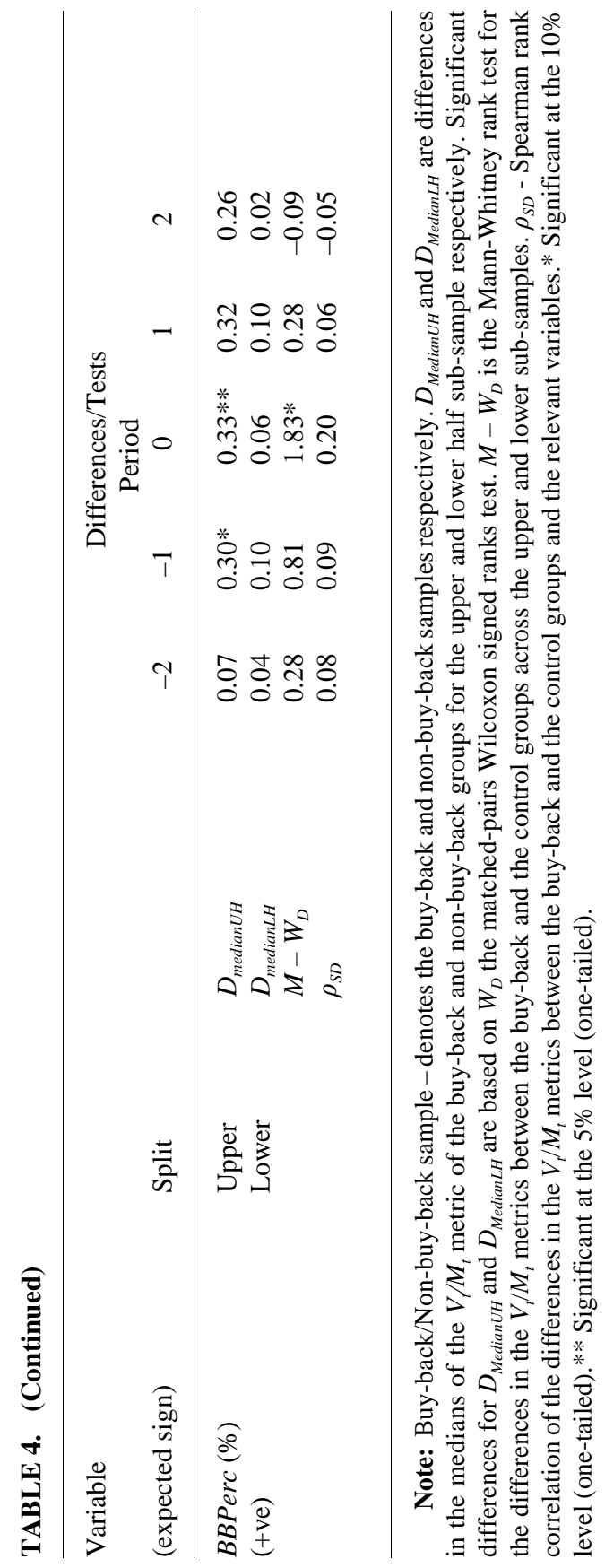


(period 0). The median $V_{t} / M_{t}$ values for the upper and lower halves for both buy-back and the matched control sample, as well as differences, and tests of these differences are then tracked separately over the full period $(-2 /+2)$. They are presented in the various columns in table 4 .

The finding is that the greater the BkMkt ratio, the greater the undervaluation. For instance, the differences between the buy-back and the control samples for the upper portion of the BkMkt values, the extent of the undervaluation is 0.56 in period -2 declining to 0.21 in period +2 . This can be contrasted to the lower half of the BkMkt portion where the differences are -0.21 declining to -0.04 in period -1 . Thus high (low) BkMkt firms have a significant positive (negative) difference of $V_{t} / M_{t}$ for the buy-back relative to the matched samples (or undervaluation) over all periods. Differences between the buy-back and the control samples for the upper and lower partition are clearly consistently significant for virtually all differences over the $(-2 /+2)$ period. Another point of interest is that the undervaluation clearly declines but is still present post the buy-back.

Differences in the $V_{t} / M_{t}$ metrics between the buy-back and the control groups across the upper and lower sub-samples are tested for significance using the Mann-Whitney rank test. Similarly, the degree of association of the various variables to the differences in $V_{t} / M_{t}$ between the buy-back and the control groups is tested using the spearman rank correlation. ${ }^{23}$ Overall, the BkMkt is positively and the MktCap is negatively related to $V_{t} / M_{t}$ over the various periods. The other variables show little relationship to the undervaluation metric.

\section{Conclusion}

Share buy-backs have become extremely popular in Australia following the lifting of the legislative barriers impeding the buy-back activity in December 1995. The main explanation for the buy-back process and the

23. Cross-sectional regressions were estimated using undervaluation as the dependent and the independent variables above but omitting the BkMkt variable. BkMkt was not included in the regression as the BkMkt is significantly and highly correlated with the $V_{t} / M_{t}$ metrics ( $\rho=0.61$ to 0.77$)$ and the undervaluation variables $(\rho=0.45$ to 0.50$)$. Thus in some ways it can be viewed as simply a proxy of the metrics. From the regression results the only variable that was consistently significant in explaining the degree of undervaluation was the $\log$ of the MktCap. All the other variables added little to the explanatory power in the multivariate cross-sectional setting and as a result the regressions are not reported or commented on in detail. 
positive capital market response that goes with the announcement is that the buy-back activity provides a signal about undervaluation. Hence, the focus of this research is to identify whether Australian on-market buy-back companies are undervalued relative to non-buy-back companies and further what is the signaling power of the buy-back. The Australian market provides an ideal and unique environment, which enables a direct test of the undervaluation explanation unlike the U.S. In Australia the motivation for the buy-back is required to be disclosed in the buy-back announcement. As an alternative to market based studies the Ohlson RIV model is used, incorporating accounting information to identify fundamental value and hence estimate undervaluation directly.

Prior to the buy-back announcement, on-market buy-back companies are generally and significantly undervalued relative to matched non-buy-back counterparts. No systematic undervaluation for the other types of buy-backs is found. In general the on-market undervaluation reduces markedly after the on-market buy-back confirming the signaling power in communicating this information to the market. That said, the undervaluation is not eliminated immediately and takes a couple of periods before it finally dissipates.

Interestingly, the pre-buy-back undervaluation is much more pronounced following the introduction of the FCLSA and is more evident prior to repeat or subsequent buy-backs. Finally, almost all the undervaluation is located in instances where undervaluation is expressed directly as a motive. Importantly, this confirms that management can identify the undervaluation and conveys the information to the market through on-market buy-backs. While the market responds to this, in situations where undervaluation is stated the signaling power of the buy-back is not as strong as it should be as some undervaluation remains after the buy-back, markedly and significantly so in the post-FCLSA period. The cross-sectional analysis reveals that the book-to-market ratio of the firm is a good proxy for the degree of relative undervaluation.

One implication of the above is that a strategy that identifies and invests in firms announcing on-market buy-backs that state a motive of undervaluation and have a high book-to-market ratio would appear to be potentially lucrative as it targets high undervaluation firms. Such a strategy would be a long-term one, as the undervaluation persists for a couple of annual periods post the buy-back. A second implication relates to countries like the U.S. and the U.K. that do not have a 
formalized announcement and required information release as part of the repurchase mechanism. Identification of undervaluation and the signaling properties of the announcement are expected to be much lower for these countries as shareholders are unsure as to when and to what extent the firm will repurchase. Other forms of information release such as management forecasts will not necessarily compensate as they are not backed with a cash payment and are thus not seen to have the same degree of credibility.

\section{References}

Abarbanell J., and Bernard, V. 2000. Is the U.S. stock market myopic? Journal of Accounting Research 38(2): 221-242.

Asquith, P., and Mullins, D.W. 1986. Signaling with dividends, stock repurchases, and equity issues. Financial Management 15(3): 27-44.

Baker, H.K.; Gallagher, P.L.; and Morgan, K.E. 1981. Management's View of Stock Repurchase Programs. Journal of Financial Research 4(3): 233-247.

Baker, H.K.; Powell, G.E.; and Veit, E.T. 2003. Why companies use open-market repurchases: A managerial perspective. The Quarterly Review of Economics and Finance 43(3): 483-504.

Barth, M.E., and Kasznik, R. 1999. Share repurchases and intangible assets. Journal of Accounting and Economics 28(2): 211-241.

Balachandran, B., and Troiano, R. 2000. On-market share buy-backs and earnings: Australian evidence. $9^{\text {th }}$ Conference on the Theories and Practices of Securities Markets. Kaohsiung: Taiwan.

Christianto, C.; Clarke, A.W.; and Mitchell, J.D. 1997. Short- and long-run performance of australian share buy-backs. AAANZ Conference. June 1997.

Comment, R., and Jarrell, G.A. 1991. The relative signaling power of Dutch-auction and fixed-price self-tender offers and open-market share repurchases. Journal of Finance 46(4): 1243-1271.

Dann, L.Y. 1981. Common stock repurchases. Journal of Financial Economics 9(2): 113-138.

Dechow, P.M.; Hutton, A.P.; and Sloan, R.G. 1999. An empirical assessment of the residual income valuation model. Journal of Accounting and Economics 26(1-3): 1-34.

Dharmawan, G.V., and Mitchell, J.D. 1999. The legislative framework of share buy-backs - A comparison of the 'old' and 'existing' requirements. University of Tasmania Law Review 18(2): 283-308.

Dharmawan, G.V., and Mitchell, J.D. 2001. Australian buy-back regulations A cross-country comparison. Australian Journal of Corporate Law 12(3): $1-36$.

Fama, E., and French, K. 1995. Size and book-to-market factors in earnings and 
returns. Journal of Finance. 50(1): 131-155.

Fama, E.F., and French, K.R. 1997. Industry costs of equity. Journal of Financial Economics 43(2): 153-193.

Frankel, R., and Lee, C.M. 1998. Accounting valuation, market expectation, and cross-sectional stock returns. Journal of Accounting and Economics 25(3): 283-319.

Francis, J.; Olsson, P.; and Oswald, D. 2000. Comparing the accuracy and explainability of dividend, free cash flow and abnormal earnings equity valuation estimates. Journal of Accounting Research 38(1): 45-70.

Hand, J.R.M. 2001. Discussion of "earnings, book values, and dividends, in equity valuation: An empirical perspective”. Contemporary Accounting Research 18(1): 121-130.

Harris, T.J., and Ramsay, I.M. 1995. An empirical investigation of australian share buy-backs. Australian Journal of Corporate Law 4(4): 393-416.

Ikenberry, D.L.; Lakonishok, J.; and Vermaelen, T. 1995. Market underreaction to open market share repurchases. Journal of Financial Economics 39(1/2): 181-208.

Imhoff, E. 1998. Fundamental analysis: The role of accounting data in valuing the firm. Unpublished Working Paper: University of Michigan.

Lamba, A.S., and Ramsay, I.M. 2000. Share buybacks in a highly regulated and less regulated market environment. Unpublished Working Paper: Department of Accounting and Finance, University of Melbourne.

Lee, C.M.; Myers, C.J.; and Swaminathan, B. 1999. What is the intrinsic value of the Dow? Journal of Finance 54(5): 1693-1741.

Lee, P.J.; Levitt, S.C.; Taylor, S.L.; and Walter, T.S. 1998. Do takeover premiums reflect undervaluation? Working Paper: University of Sydney.

Li, K., and McNally, W. 1999. Information signaling or agency conflicts: What explains Canadian open market share repurchases? Working paper: University of British Columbia and University of Victoria.

Liu, C.S., and Ziebart, D.A. 1997. Stock returns and open-market stock repurchase announcement. Financial Review 32(3): 709-728.

Mitchell, J.D., and Robinson, P. 1999. Motivations of Australian listed companies effecting share buy-backs. ABACUS 35(1): 91-119.

Mitchell, J.D.; Dharmawan, G.V.; and Clarke, A.W. 2001. Managements' views on share buy-backs: An Australian survey. Accounting and Finance 41(1/2): 93-129.

Ohlson, J.A. 1995. Earnings, book values, and dividends in security valuation. Contemporary Accounting Research 11(2): 661-687.

Ohlson, J.A. 2001. Earnings, book value and dividends in equity valuation: An empirical perspective. Contemporary Accounting Research 18(1): 107-120.

Otchere, I., and Ross, M. 2002. Do share buy-back announcements convey firm-specific or industry-wide information? A test of the undervaluation hypothesis. International Review of Financial Analysis 11(4): 511-531.

Penman, S.H., and Sougiannis, T. 1998. A comparison of dividend, cash flow, 
and earnings approaches to equity valuation. Contemporary Accounting Research 15(3): 343-383.

Pugh, W., and Jahera, J.S. Jr. 1990. Stock repurchases and excess returns: An empirical examination. Financial Review 25(1): 127-142.

Ratner, M.; Szewczyk, S.H.; and Tsetsekos, G.P. 1996. The informational role of tender offer stock repurchases: Evidence from institutional ownership. Journal of Business Finance \& Accounting. 23(5)\&(6): 869-880.

Stephens, C.P., and Weisbach, M.S. 1998. Actual share reacquisitions in open-market repurchase programs. Journal of Finance 53(1): 313-333.

Stewart, S.S. 1976. Should a corporation repurchase its own stock? Journal of Finance 31(3): 911-921.

Tsetsekos, T.P.; Kaufman, D.; and Gitman, L.J. 1991. A survey of stock repurchase motivations and practices of major U.S. corporations. Journal of Applied Business Research 7(3): 15-21.

Vermaelen, T. 1981. Common stock repurchases and market signaling: An empirical study. Journal of Financial Economics 9(2): 139-183.

Wansley, J.W., Lane, W.R., and Sarkar, S. 1989. Managements' view on share repurchase and tender offer premium. Financial Management 18(3): 97-110. 